\title{
The first report of Aedes (Stegomyia) albopictus in Haiti
}

\author{
María del Carmen Marquetti Fernández ${ }^{1 /}$, Yvan Saint Jean², \\ Carlos A Fuster Callaba', Lorenzo Somarriba López ${ }^{1}$ \\ ${ }^{1}$ Cuban Medical Brigade in Haiti, Rue Delmas 83, Commune Delmas, Port au Prince, Haiti \\ ${ }^{2}$ Malaria and Lymphatic Filariasis Programme, Haiti
}

Aedes albopictus was found in six of the 10 departments of Haiti and in 14 of the 35 communes surveyed. The survey found the larvae of Ae. albopictus in 13 different types of containers. Used tires and tins were by far the most common breeding sites used by this mosquito species. At the breeding sites, Ae. albopictus was associated with other mosquito species, such as Aedes aegypti, Culex nigripalpus and Aedes mediovittatus. The highest proportion of association was with Ae. aegypti. This study represents the first report of Ae. albopictus in Haiti.

Key words: Aedes albopictus - habitats - Haiti

Aedes albopictus has spread throughout America, Europe, Africa and Oceania during recent decades from its original area of distribution in southeast Asia (Forattini 1986, Sprenger \& Wulthiranyagool 1986, Gonzalez \& Marro 1999, Fontenille \& Toto 2001, Gratz 2004, Schaffner et al. 2004, Gimenez et al. 2007, Scholte et al. 2007, Wymann et al. 2008, Navarro et al. 2009, Gatt et al. 2010). Ae albopictus has been reported in the Dominican Republic, located east of Haiti on the island of Hispaniola (Peña 1993). However, information about the presence of this mosquito in Haiti is not available. Ae. albopictus is susceptible to several arbovirus infections and is capable of transmitting at least 24 of them. In particular, Ae. albopictus is susceptible to oral infection by the following diseases, which can be transmitted by the bites of this mosquito: dengue, eastern equine encephalitis, Potosi, Chikungunya, La Crosse encephalitis and West Nile. Additional diseases are similarly associated with this species (Gerhardt et al. 2001, Sardelis et al. 2002, Benedict et al. 2007, Dehecq et al. 2011). The aims of this paper are to document the presence of Ae. albopictus in Haiti and to report its breeding sites and association with other mosquito species in the country. Haiti is located in the western part of the island of Hispaniola. Its capital, Port au Prince, was severely damaged by an earthquake in January 2010. Sampling was conducted in 35 communes belonging to the 10 departments that constitute the Republic of Haiti. Water can collect in containers in the courtyards of the houses. These containers were inspected as part of a program established to monitor Aedes aegypti in the period from May-December 2010. It should be noted that sampling was conducted only from the exterior of the premises and homes. All containers with water were examined, but inspections were

+ Corresponding author: marquetti@ipk.sld.cu

Received 26 July 2011

Accepted 18 October 2011 not performed inside the houses out of respect for the customs of the local population. The survey included all human settlements and tents used as local housing. Such housing units are common in areas affected by the earthquake. The survey covered a radius of one kilometre around the Community Reference Hospitals operated by the Cuban Medical Brigade in Haiti. The work was performed by trained vector control personnel located in each area studied. Up to 20 mosquito larvae, depending on the container size, were collected per sample using a $3 \mathrm{~mL}$ plastic pipette and placed in vials of $70 \%$ alcohol. The vials were labelled with the data collection site, date and container type. Illustrated keys for the mosquito vectors of dengue were used to identify the samples (Rueda 2004, Gonzalez 2006). Ae. albopictus was found in six of the 10 departments of the Republic of Haiti. The mosquito was found in $14(40 \%)$ of the 35 communes surveyed. The departments, communes and number of containers with $A e$. albopictus were as follows: Arcahiae (2), Thomazeau (7), Carrefour (9), Port-au-Prince (2) (west department), Cayes Jacmel (2) (southeast department), Saint-Marc (9), Verrettes (14) (department of Artibonite), Corail (2), Jeremie (2), Anse du Hainault (2) (department of Grand Anse), Port Salut (9), Camp Perrin (6), Les Cayes (2) (southern department) and Mirebalais (6) (centre department) (Figure). The survey found larvae of Ae. albopictus in 13 different types of containers. Used car tires $(19,25.7 \%)$ and tins $(10,13.6 \%)$ were by far the most frequent types of breeding sites used by this species (Table I). At the breeding sites, Ae. albopictus was associated with other mosquito species, such as Ae. aegypti, Culex nigripalpus and Aedes mediovittatus. Of the 74 containers in which Ae. albopictus was found, $43.2 \%$ harboured only Ae. albopictus, whereas the other containers harboured one or more additional mosquito species. The highest proportion of association, $76.2 \%$ (32/42), was with Ae. aegypti. (Table II). Only 14 of the 35 communes surveyed reported the presence of Ae. albopictus. However, this finding does not mean that this species is not present in the other communes. It is necessary to develop further research on this mosquito, primarily in rural areas and during other periods of the year, 


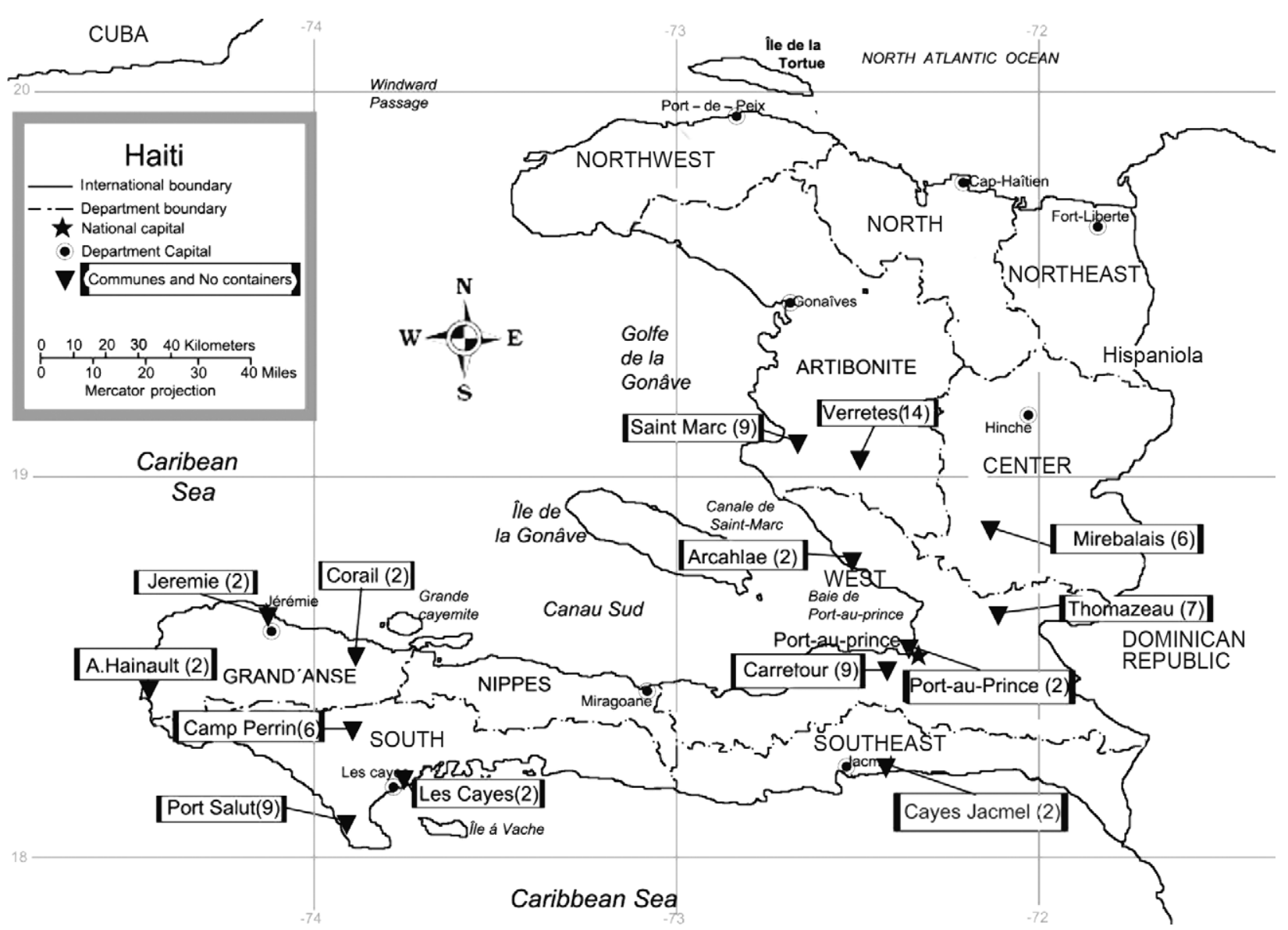

Distribution of the communes and number of containers with Aedes albopictus presence in Haiti.

TABLE I

Number of containers with Aedes albopictus larval presence, Haiti, 2010

\begin{tabular}{lc}
\hline Type of container & $\begin{array}{c}\text { Containers } \\
\mathrm{n}(\%)\end{array}$ \\
\hline Tree hole & $7(9.4)$ \\
Car used tires & $19(25.7)$ \\
Drums $>30$ gallons (metal, plastic, cement) & $4(5.4)$ \\
Tins & $10(13.6)$ \\
Little drums $<30$ gallons & $7(9.4)$ \\
(metal, plastic, cement) & \\
Bottles & $3(4.1)$ \\
Cartoon boxes & $2(2.7)$ \\
Car, fridges, other electro domestic & $7(9.4)$ \\
equipment discarded & \\
Plates under flower pots & $2(2.7)$ \\
Animal drinking bowls & $2(2.7)$ \\
Cisterns & $2(2.7)$ \\
Plastic cups & $4(5.4)$ \\
Bowls & $5(6.8)$ \\
\hline Total & 74 \\
\hline
\end{tabular}

to obtain additional information and to obtain a complete picture of the distribution of Ae. albopictus in the country. Several factors affect the dispersal and establishment of Ae. albopictus in Haiti. Climatic factors favour the development and the life cycle of this mosquito. The steady migration of populations between departments in search of better living conditions favours the passive transport of this mosquito by road or other vehicles carrying the adult stage. In addition, the species can be dispersed and established from mosquito eggs in used tires in illegal landfill in both urban and rural areas.

All these factors, in combination with the intrinsic genetic variability of Ae. albopictus and the ability of the species to adapt physiologically and ecologically, promote the rapid colonisation of new areas (Gratz 2004, Paupy et al. 2009).

Moreover, this study demonstrated the reported ability of Ae. albopictus to complete its pre-imaginal development in a wide variety of containers, primarily generated by human activities. The earthquake that Haiti experienced in January 2010 caused a deterioration of the infrastructure in much of the country. The population faced a water supply crisis and environmental management worsened. In general, sanitation is poor in the communes. The presence of a variety of containers facilitates the breeding of Ae. albopictus. This mosquito's use of such containers to support its ecological plasticity 


\section{TABLE II}

Aedes albopictus and its association with other mosquito species, Haiti, 2010

\begin{tabular}{lc}
\hline $\begin{array}{l}\text { Mosquito association } \\
\text { Ae. albopictus }\end{array}$ & $\begin{array}{c}\text { Containers } \\
\mathrm{n}(\%)\end{array}$ \\
$\begin{array}{l}\text { Sub total container with } \\
\text { one mosquito specie }\end{array}$ & $32(43.2)$ \\
Aedes aegypti-Ae. albopictus & $32(43.2)$ \\
$\begin{array}{l}\text { Ae. albopictus-Aedes mediovittatus } \\
\text { Ae. albopictus-Culex nigripalpus }\end{array}$ & $32(43.2)$ \\
$\begin{array}{l}\text { Ae. albopictus-Ae. aegypti- } \\
\text { Ae. mediovittatus }\end{array}$ & $6(8.2)$ \\
$\begin{array}{l}\text { Sub total container with two } \\
\text { or more mosquito species }\end{array}$ & $2(2.7)$ \\
\hline Total & $2(2.7)$ \\
\hline
\end{tabular}

and behaviour is similar to that reported from different areas of the world (Estrada \& Craig 1995, Marquetti et al. 2000, Gratz 2004, Valdés et al. 2009). The current study is the first report of the presence of Ae. albopictus in Haiti. There is a need for additional studies on its distribution and behaviour, its association and competition with other species and its possible role in the transmission of dengue and other viral diseases in the country.

\section{REFERENCES}

Benedict MQ, Levine RS, Hawley WA, Lounibos LP 2007. Spread of the tiger: global risk of invasion by the mosquito Aedes albopictus. Vector Borne Zoonotic Dis 7: 76-85.

Dehecq JS, Baville M, Marqueron T, Mussard R, Filleul L 2011. The remergence of the Chikungunya virus in Reunion Island on 2010. Evaluation of the mosquito control practices. Bull Soc Pathol Exot 2: 153-160.

Estrada GJ, Craig BJ 1995. Biología, relaciones con enfermedades y control de Aedes albopictus. Cad Tec OPS 42: 1-43.

Fontenille D, Toto JC 2001. Aedes (Stegomyia) albopictus (Skuse), a potential new dengue vector in southern Cameroon. Emerg Infect Dis 7: 920-921.

Forattini OP 1986. Identificacão de Aedes (Stegomyia) albopictus no Brasil. Rev Saude Publica 20: 244-245.

Gatt P, Schaffner F, Cassai F 2010. Aedes (Stegomyia) albopictus (Skuse) (Diptera: Culicidae) in Malta, the first winter. Eur Mosq Bull 28: 225-229.
Gerhardt RR, Gottfried KL, Apperson CS, Davis BS, Erwin PC, Smith AB 2001. First isolation of La Crosse virus from naturally infected Aedes albopictus. Emerg Inf Dis 7: 807-811.

Giménez N, Barahona M, Casasa A, Domingo A, Gavagnach M, Martí C 2007. Llegada de Aedes albopictus a España, un nuevo reto para la salud pública. Gaceta Sanitaria: órgano oficial de la Sociedad Española de salud pública y administración sanitaria [cited 2011 Mar 20]. Available from: revbiomed.uady.mx/pdf/rb092022.pdf.

González R 2006. Culícidos de Cuba, 2nd ed., Editorial Científico Técnica, La Habana, 184 pp.

González R, Marro E 1999. Aedes albopictus in Cuba. J Am Mosq Control Assoc 15: 569-570.

Gratz NG 2004. Critical review of the vector status of Aedes albopictus. Med Vet Entomol 18: 215-227.

Marquetti MC, Valdés V, Aguilera L 2000. Tipificación de habitas de Aedes albopictus en Cuba y su asociación con otras especies de culícidos 1995-1998. Rev Cub Med Trop 52: 170-174.

Navarro JC, Zorrilla A, Moncada N 2009. Primer reporte de Aedes albopictus (Skuse) en Venezuela. Importancia como vector de dengue y acciones a desarrollar. Bol Mal Salud Amb 49: 1.

Paupy C, Delatte H, Bagny L, Corbel V, Fontenille D 2009. Aedes albopictus, an arbovirus vector: from the darkness to the light. Microbes Infect 11: 1177-1185.

Peña C 1993. First report of Aedes (Stegomyia) albopictus from the Dominican Republic. Vect Ecol News 24: 4-5

Rueda LM 2004. Pictorial keys for the identification of mosquitoes (Diptera: Culicidae) associated with dengue virus transmission, Zootaxa Magnolia Press, Auckland, 60 pp.

Sardelis MR, Turell MJ, O'Guinn ML, Andre RG, Roberts DR 2002. Vector competence of three North American strains of Aedes albopictus for West Nile virus. J Am Mosq Control Assoc 18: 284-289.

Schaffner F, Van Bortel W, Coosemans M 2004. First record of Aedes (Stegomyia) albopictus in Belgium. J Am Mosq Control Assoc 20: 201-203.

Scholte EJ, Jacobs F, Linton YM, Dijkstra E, Fransen J, Takken W 2007. First record of Aedes (Stegomyia) albopictus in the Netherlands. Eur Mosq Bull 22: 5-9.

Sprenger D, Wulthiranyagool T 1986 . The discovery and distribution of Aedes albopictus in Harris County, Texas. J Am Mosq Control Assoc 2: 217-219.

Valdés V, Marquetti MC, Pérez K, González R, Sánchez L 2009. Distribución espacial de los sitios de cría de Aedes albopictus (Diptera:Culicidae) en Boyeros, Ciudad de la Habana, Cuba. Rev Biomed 20: 72-80.

Wymann MN, Flacio E, Radczuweit S, Patocchi N, Lüthy P 2008. Asian tiger mosquito (Aedes albopictus) - A threat for Switzerland? Euro Surveill [serial on the internet]. [cited 2009 Feb 22]. Available from: eurosurveillance.org/ViewArticle. aspx?ArticleId=8058. 